UDC 665.7.038

\title{
MULTIFUNCTIONAL ADDITIVE FOR MOTOR OILS ON THE BASIS OF DODECYLPHENOL
}

\author{
E.A.Naghiyeva, A.K.Kazim-zadeh, Kh.N.Mammadyarova, A.A.Gadirov, M.N.Aliyeva, \\ Y.B.Ramazanova
}

A.Guliyev Institute of Chemistry of Additives, NAS of Azerbaijan

aki05@mail.ru

Received 29.01.2019

\begin{abstract}
The results on synthesis and research of high alkaline alkylphenolate AKI-134 additive have been introduced. AKI-134 additive is a carbonated calcium salt of the condensation product of dodecylphenol, formaldehyde, ammonia and $p$-aminobenzoic acid. Due to the presence of 2 nitrogen atoms, carboxylate and phenolate groups, the additive shows high anticorrosion, antioxidative and detergent properties. Using AKI-134 additive and commodity additives the $\mathrm{M}-10 \Gamma_{2}$ motor oil has been developed that by their physical-chemical and functional properties meet the standards.
\end{abstract}

Keywords: dodecylphenol, formaldehyde, ammonia, p-aminobenzoic acid, additive, motor oil.

https://doi.org/10.32737/0005-2531-2019-2-48-51

\section{Introduction}

The improvement of the design of internal combustion engines leads to increased demands on the quality of motor oils.

Application of the effective additives is one of the more progressive methods for the quality increase of motor oils.

In composition of modern motor oils as one of the main components a significant part is given to detergent-dispersant additives.

This group of additives includes alkylphenolates, sulphonates and alkylsalicylates. Alkylphenolate additives are found in most modern motor oils. This is due to the availability of raw materials, simple technology of production and multifunctionality of alkylphenolate additives [1-4].

Up to the middle of 1990 in the republics of CIS, most of the alkylphenolate type detergent-dispersant additives produced in industry were barium containing products (BFK, IKhP101, SIATIM-339 and others). Low alkalinity and high ash content of these additives were the main reason for the reduction or cessation of production of these obsolete additives [5], that didn't meet modern requirements and were inferior to foreign analogues (Амоко-9230, Paranox-51 and others). However they had fulfilled their mission, at that time. By using them, various types of motor oils were developed. In this regard, there is an urgent need to update the range of alkylphenolate additives and improve their quality.

Analysis of scientifico-, technical and patent literature of the last decade showed that of particular interest are high alkaline carbonated alkylphenolates containing metal (most often calcium).

The most perspective are high alkaline multifunctional additives that in low in small concentrations at the same time improve some properties of lubricating oils [6].

High alkalinity indicates high neutralizing properties of additives [7].

The need in high alkaline multifunctional additives is due to their ability to show high neutralizing and detergent properties in composition of lubricating oils [8].

By introducing various heteroatoms and functional groups into the additive molecules, their antioxidant, anticorrosive and detergent properties are improved [9, 10].

It is known that among metal containing additives for oils alkylsalicylate additives that possess high detergent, thermo-oxidative and other properties have also found wide application. However, in industry they are produced by multi-stage technology, which ultimately complicates the creation of the production technology of this type of additives $[11,12]$. 


\section{Experimental part}

In connection with the above, we have proposed a method of obtaining new multifunctional additive for motor oils - AKI-134, which combine simultaneously the properties of alkylphenolate and alkylsalicylate additives.

The process of obtaining the additive includes the following main stages:

- sequential condensation of dodecylphe- nol with formaldehyde, ammonia and $p$ aminobenzoic acid;

- neutralization of condensation product by calcium hydroxide;

- carbonation of neutralization products and desiccation;

- separation of mechanical impurities by centrifugation.

The estimated formula for AKI-134 additive is:

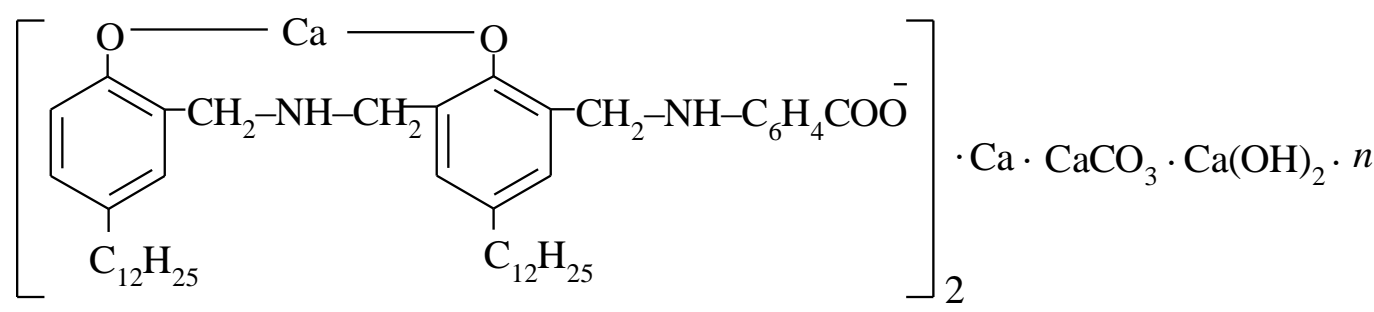

The additive is a viscous lIRuid that is of 130-150 mg KOH/g alkaline number.

Following optimal conditions for obtaining additive: dodecylphenol:ammonia:formalin:p-aminobenzoic acid: $\mathrm{Ca}(\mathrm{OH})_{2}-100:(30$ 35):(40-45):(10-12):(35-40) were established. During carbonation 5\% (of alkylphenol) ethylene glycol was used as a promoter. The structure of derived additive has been confirmed by IR spectroscopy that was performed on "Nicolet is 10" spectrometer around $400-4000 \mathrm{~cm}^{-1}$.

In the IR spectrum of the product dodecylphenol condensation with formaldehyde, ammonia and $p$-aminobenzoic acid, bands of absorption of the $\mathrm{OH}$ group of the phenolic compound, $\mathrm{OH}$ group of $p$-aminobenzoic acid and $\mathrm{NH}$ group around $3200-3500 \mathrm{~cm}^{-1}$ were detected.

Valence vibrations of $\mathrm{CO}$ groups are registered around $v_{\mathrm{c}=0}-1716 \mathrm{~cm}^{-1}\left(1690-1760 \mathrm{~cm}^{-1}\right)$, and $\mathrm{CN}$ bond around $-1181 \mathrm{~cm}^{-1}$ [13].

After the neutralization of condensation product by calcium hydroxide the $3408 \mathrm{~cm}^{-1}$, stripe appears that is characteristic to valence vibrations of $\mathrm{NH}$ group, which was previously covered by $\mathrm{OH}$ condensation groups. In the IR spectrum of the neutralization product, the band of stretching vibrations of the $\mathrm{CO}$ of the acid group of $1716 \mathrm{~cm}^{-1}$ disappeared and the corresponding carboxylate of the $\mathrm{COO}^{-}$ions appeared symmetric and asymmetric $v_{\mathrm{COO}}^{\text {sim }}=1349$ $\mathrm{cm}^{-1}$ and $v_{\mathrm{COO}}^{\text {as }}=1580 \mathrm{~cm}^{-1}$ instead of it. Regarding calcium hydroxide, in the neutralization product there are absorption bands corresponding to the $\mathrm{OH}$ group $v_{\mathrm{OH}}=3670 \mathrm{~cm}^{-1}$ and $\mathrm{CO}_{3}$ group of the average intensity band $v_{\mathrm{CO}_{3}^{2-}}^{2-}=1430$ and $860 \mathrm{~cm}^{-1}$.

\section{Results and discussion}

Physico-chemical and functional properties of AKI-134 additive have been studied in the composition of the M-8 oil using the following standard methods.

Anticorrosive properties were determined according to ГОСТ 20502-75, anti-oxidative properties according to ГОСТ 11063-77, detergent properties according to ГОСТ 5726-2013.

Physico-chemical and functional properties of test additive in composition of M-8 oil are shown in Table 1, where for comparison the data of foreign commodity additives VNIINP-714, OLOA-218A and MASK are also presented. 
Table 1. Physico-chemical and functional properties of alkylphenolate additives

\begin{tabular}{|c|c|c|c|c|c|c|}
\hline \multirow[b]{2}{*}{ Additive } & \multicolumn{3}{|c|}{$\begin{array}{l}\text { Physico-chemical and functional properties } \\
\text { of additives }\end{array}$} & \multicolumn{3}{|c|}{ M- 8 oil $+5 \%$ additive } \\
\hline & $\begin{array}{c}\text { alkali number, } \\
\mathrm{mg} \mathrm{KON} / \mathrm{g}\end{array}$ & $\begin{array}{l}\text { sulfate ash } \\
\text { content, } \\
\%\end{array}$ & $\begin{array}{c}\text { kinematic visco- } \\
\text { sity, at } 100^{0} \mathrm{C} \\
\mathrm{mm}^{2} / \mathrm{s}\end{array}$ & $\begin{array}{c}\text { corrosiveness } \\
\text { (in lead plates), } \\
\mathrm{g} / \mathrm{m}^{2}\end{array}$ & $\begin{array}{c}\text { *stability by induction } \\
\text { period of precipitation } \\
\text { (IPP } 30 \mathrm{~h} \text { of prec., } \\
\%\end{array}$ & $\begin{array}{c}\text { detergent proper- } \\
\text { ties (on PZV), } \\
\text { point }\end{array}$ \\
\hline AKI-134 & 145.2 & 16.1 & 72.2 & 1.0 & absent & 0.5 \\
\hline AKI-134 & 150.1 & 16.6 & 74.8 & 0.9 & absent & 0.5 \\
\hline VNIINP-714 & 143.0 & 17.2 & - & 6.4 & absent & 0.5 \\
\hline OLOA-218A & 147.0 & 17.6 & - & 9.8 & absent & 0.5 \\
\hline \begin{tabular}{l|l} 
MASK \\
\end{tabular} & 140.0 & 16.8 & - & 4.5 & absent & 0.5 \\
\hline
\end{tabular}

*precipitation up to $0.5 \%$ is considered absent

Table 2. Physico-chemical and functional properties of $\mathrm{M}-10 \Gamma_{2}$ motor oil

\begin{tabular}{|c|c|c|c|}
\hline Indicators & $\begin{array}{l}\text { ГOCT 8581-92 } \\
\text { (norm) }\end{array}$ & Test oil M-10 $\Gamma_{2}$ & $\begin{array}{l}\text { Shell oil Rimula } \\
\text { C30 }\end{array}$ \\
\hline Kinematic viscosity at $100^{\circ} \mathrm{C}, \mathrm{mm}^{2} / \mathrm{s}$ & $11 \pm 0.5$ & 11.45 & 10.8 \\
\hline Viscosity index, no more than & 90 & 90 & 102 \\
\hline $\begin{array}{l}\text { Alkali number, } \mathrm{mg} \mathrm{KON} / \mathrm{g} \text {, } \\
\text { no more than }\end{array}$ & 6.0 & 7.4 & 9.4 \\
\hline Sulfate ash content, $\%$, no more than & 1.65 & 1.26 & 1.3 \\
\hline $\begin{array}{l}\text { Flash point in open crucible, }{ }^{0} \mathrm{C}, \\
\text { no lower than }\end{array}$ & 205 & 205 & 202 \\
\hline Freezing point, ${ }^{0} \mathrm{C}$, no lower than & minus 15 & minus 15 & minus 15 \\
\hline $\begin{array}{l}\text { Stability by induction period of precipitation } \\
\text { (IPP) resistance, } h\end{array}$ & 40 & 40 & 40 \\
\hline Corrosion (in lead plates), $\mathrm{g} / \mathrm{m}^{2}$, no more than & 20 & absent & absent \\
\hline Detergent properties (on ELV), point & 1.0 & 0.5 & 0.5 \\
\hline
\end{tabular}

As can be seen on data from Table 1, under the conditions of the tests of test additive AKI-134 on anticorrosion properties surpass comparable industrial analogues, and on antioxidative and detergent properties are on the same level with them.

The improvement of exploitative properties of the additive is apparently related to the mutual influence of 2 nitrogen atoms, carboxylate and phenolate groups on the formation of a stable colloidal dispersion.

Synthesized AKI-134 additive in combination with commodity additives has been studied in the composition of the $\mathrm{M}-10 \Gamma_{2}$ motor oil.

Results of $\mathrm{M}-10 \Gamma_{2}$ oil analysis are shown on Table 2, there are also physico-chemical and functional properties of the foreign analogue Shell oil.

From data on Table 2, we can see that M-10 $\Gamma_{2}$ oil with AKI-134 additive meet the requirements of ГOCT-8581-92 on exploitation properties and is not inferior to the foreign counterpart.

\section{Conclusion}

Thus, the possibility of using AKI-134 additive in the composition of $\mathrm{M}-10 \Gamma_{2}$ motor oil as the main component instead of ИХП-101 additive (barium alkylphenolate) is shown.

This work has been carried out with the financial support of the Foundation for the Development of Science under the President of the Republic of Azerbaijan - Grant №EIF / GAM4-BGM-GIN 2017-3(29)-19/05/4.

\section{References}

1. Kirichenko G.N., Glazunova V.I., Desiatkin A.A., Ibragimov A.G., Dzhamilov U.M. Sintez novykh polifunktcionalnykh prisadok $\mathrm{k}$ smazochnym maslam. Zhurn. pricl. himii. 2009. T. 82. № 1. S. 94-98.

2. Moiseeva L.S. Prisadki mnogofunktcionalnogo naznacheniia - alkilfenoliaty: sovershenstvovanie sposobov polucheniia. Tekhnologiia mashinostroeniia. 2012. № 10. S. 37-47.

3. Kiazim-zade A.K., Nagieva E.A., Mamedova A.Kh., Mamedova R.A., Nasirova S.I. Polifun- 
ktcionalnaia prisadka $\mathrm{k}$ smazochnym maslam. Azerb. neftianoe hoz-vo. 2013. № 9. S. 59-61.

4. Selezneva I.E., Levin A.Ia., Monin S.V. Detergentno-dispergiruiushchie prisadki $\mathrm{k}$ motornym maslam. Himiia i tekhnologiia topliv i masel. 1999. № 6. S. 39-43.

5. Selezneva I.E., Levin A.Ia., Trofimova G.L., Ivanova O.V., Budanovskaia G.A. Novaia sverkhshchelochnaia alkilfenol`naia prisadka $\mathrm{k}$ motornym maslam. Himiia i tekhnologiia topliv i masel. 2009. № 4. S. 10-12.

6. Farzaliev V.M., Ismailova N.D., Musaeva M.E. Prisadki k smazochnym maslam: Istoriia nauki. Baku: Elm, 2009. 232 s.

7. Lashhi V.L., Leimeter T., Shor G.I., Falkovich M.I. Shelochnoe chislo kak pokazatel sovmestimosti prisadok $\mathrm{k}$ motornym maslam. Himiia i tekhnologiia topliv i masel. 2000. № 4. S. 10-12.

8. Mamedova A.Kh., Kiazim-zade A.K., Nagieva E.A. Novye alkilfenoliatnye prisadki k smazoch- nym maslam. Neftepererabotka i neftehimiia. 2010. № 9. S. 28-29.

9. Kazımzadə Ә.K., Nağıyeva E.Ә., Məmmədyarova X.N., Qədirov Ә.Ә., İbadova S.Y. Çoxfunksiyalı alkilfenolyat aşqarı modifikasiyası. Azərb. Neft Təsərrüfat1. 2016. № 5. S. 44-46.

10. Kazımzadə Ә.К., Nağıyeva E.Ә., Qədirov Ә.Ә., Məmmədova R.Ө., Nəsirova S.İ. Yeni çoxfunksiyalı alkilfenolyat aşqarı modifikasiyası. Azərb. Neft Təsərrüfat1. 2015. № 5. S. 41-43.

11. Zhurba A.S., Burlakova G.G., Burgov V.A. Effektivnost proizvodstva prisadok $\mathrm{k}$ maslam. Kiev: Naukova Dumka, 1990. 182 s.

12. Vipper A.B. Antioxidant properties of engine oil detergent additives. Lubr. Sci. 1996. V. 9. № 1. P. 61-70.

13. Nakanisi K. Infrakrasnye spektry i stroenie organicheskikh soedinenii. M.: Mir. 1965. 216 s.

\title{
MOTOR YAĞLARINA DODESILLFENOL OSASINDA ÇOXFUNKSIYYALI AŞQAR
}

\author{
E.Ө.Nağıyeva, Ә.K.Kazımzadə, X.N.Məmmədyarova, Ә.ə.Qədirov, M.N.Oliyeva, Y.B.Ramazanova
}

Məqalədə yüksək qələvili AKİ-134 alkilfenolyat aşqarının sintezi və tədqiqi verilmişdir. AKİ-134 aşqarı dodesilfenolun formaldehid, ammonyak və p-aminobenzoy turşusunun kondensləşmə məhsulunun karbonatlaşmış kalsium duzudur. Aşqar molekulunda iki azot atomu karboksilat və fenolyat qruplarının birgə təsiri sayəsində yüksək korroziyaya, oksidləşməyə qarşı davamlı və yuyuculuq xassələrinə malikdir. AKİ-134 və əmtəə aşqarlarını istifadə etməklə, fizikikimyəvi və funksional xassələrinə görə standart normalarına cavab verən $\mathrm{M}-10 \Gamma_{2}$ motor yağ 1 işlənib hazırlanmışdır.

Açar sözlor: dodesilfenol, formaldehid, ammonyak, p-aminobenzoy turşusu, aşqar, motor yağl.

\section{МНОГОФУНКЦИОНАЛЬНАЯ ПРИСАДКА К МОТОРНЫМ МАСЛАМ НА ОСНОВЕ ДОДЕЦИЛФЕНОЛА}

\section{Э.А.Нагиева, А.К.Кязим-заде, Х.Н.Мамедьярова, А.А.Гадиров, М.Н.Алиева, Ю.Б.Рамазанова}

Приведены результаты по синтезу и исследованию высокощелочной алкилфенолятной присадки АКІे-134. Присадка AKİ-134 представляет собой карбонизированную кальциевую соль продукта конденсации додецилфенола, формальдегида, аммиака и $n$-аминобензойной кислоты. Присадка обладает высокими антикоррозионными, антиокислительными и моющими свойствами благодаря взаимному влиянию 2-х атомов азота, карбоксилатной и фенолятной групп на свойства присадки. С применением присадки АКІे-134 и товарных присадок разработано моторное масло М-10 $\Gamma_{2}$, которое по своим физико-химическим и функциональным свойствам соответствует стандартам.

Ключевые слова: додецилфенол, формальдегид, аммиак, п-аминобензойная кислота, присадка, моторное масло. 